\title{
Suppression of cancer stem-like phenotypes in NCI-H460 lung cancer cells by vanillin through an Akt-dependent pathway
}

\author{
SONGPOL SRINUAL ${ }^{1,2}$, PITHI CHANVORACHOTE ${ }^{1,2}$ and VARISA PONGRAKHANANON ${ }^{1,2}$ \\ ${ }^{1}$ Department of Pharmacology and Physiology, ${ }^{2}$ Cell-Based Drug and Health Product Development Research Unit, \\ Faculty of Pharmaceutical Sciences, Chulalongkorn University, Bangkok 10330, Thailand
}

Received December 6, 2016; Accepted February 6, 2017

DOI: 10.3892/ijo.2017.3879

\begin{abstract}
Cancer stem cells (CSCs) have been reported as a major cause of cancer metastasis and the failure of cancer treatment. Cumulative studies have indicated that protein kinase $\mathrm{B}(\mathrm{Akt})$ and its downstream signaling pathway, including CSC markers, play a critical role in the aggressive behavior of this cancer. In this study, we investigated whether vanillin, a major component in Vanilla planifolia seed, could suppress cancer stemness phenotypes and related proteins in the human non-small cell lung cancer NCI-H460 cell line. A non-toxic concentration of vanillin suppressed spheroid and colony formation, two hallmarks of the cancer stemness phenotype, in vitro in NCI-H460 cells. Western blot analysis revealed that the CSC markers CD133 and ALDH1A1 and the associated transcription factors, Oct4 and Nanog, were extensively downregulated by vanillin. Vanillin also attenuated the expression and activity of $\mathrm{Akt}$, a transcription regulator upstream of CSCs, an action that was confirmed by treatment with the Akt inhibitor perifosine. Furthermore, the ubiquitination of Akt was elevated in response to vanillin treatment prior to proteasomal degradation. This finding indicates that vanillin
\end{abstract}

Correspondence to: Dr Varisa Pongrakhananon, Department of Pharmacology and Physiology, Faculty of Pharmaceutical Sciences, Chulalongkorn University, 254 Phayathai Road, Pathumwan, Bangkok 10330, Thailand

E-mail: varisa.p@pharm.chula.ac.th

Abbreviations: ABCG2, ATP-binding cassette subfamily G member 2; ALDH1A1, aldehyde dehydrogenase 1 family member A1; Akt, protein kinase B; CSCs, cancer stem cells; DMSO, dimethyl sulfoxide; MTT, 3-(4,5-dimethylthiazol-2-Yl)-2,5-diphenyltetrazolium bromide; EDTA, ethylenediamine tetraacetic acid; FBS, fetal bovine serum; NSCLC, non-small cell lung cancer; Oct4, octamer-binding transcription factor 4; P-Akt, active Akt (phosphorylated at Ser473 and Thr308 residues); PBS, phosphate-buffered saline; PI, propidium iodide; PMSF, phenylmethylsulfonyl fluoride; RPMI, Roswell Park Memorial Institute; TBST, Tris-buffered saline solution with $1 \%$ Tween-20

Key words: cancer stem cells, octamer-binding transcription factor 4, protein kinase B, proteasomal degradation, ubiquitin, vanillin can inhibit cancer stem cell-like behavior in NCI-H460 cells through the induction of Akt-proteasomal degradation and reduction of downstream CSC transcription factors. This inhibitory effect of vanillin may be an alternative approach in the treatment against lung cancer metastasis and its resistance to chemotherapy.

\section{Introduction}

Lung cancer has been reported as a major cause of mortality with a high metastasis rate compared with other types of cancers (1). Lung cancer cells contain a small population called tumor-initiating cells or cancer stem cells (CSCs) that have extremely tumorigenic, self-renewal and differentiating properties, resulting in a prolonged tumor status, resistance to chemotherapy and cancer relapse $(2,3)$. Clinical observation has reported that this CSC subpopulation is found in cancer specimens and remains an obstacle for cancer treatment (4). In vitro and in vivo studies have revealed that lung cancer stem cells are extensively resistant to the first-line therapy cisplatin compared with neighboring cancer cells $(5,6)$. These CSCs can maintain the cell survival signaling that provides their strength under severe environments (7). Therefore, the attenuation or removal of CSCs would be likely to improve patient outcome.

Like other types of stem cells, CSCs express specific surface markers, including octamer-binding transcription factor 4 (Oct4), Nanog, ATP-binding cassette subfamily G member 2 (ABCG2), and CD133. Oct4 and Nanog are transcription factors that are responsible for maintaining pluripotency, self-renewal proliferation and tumorigenicity in both normal stem cells and cancer stem cells $(8,9)$. Several studies have reported that an elevation of Oct4 and Nanog is tightly related to a low survival rate and high incidence of cancer metastases $(10,11)$. In lung cancer, both Oct4 and Nanog are required to maintain the CSC-like phenotype (12). Overexpression of Oct4 and Nanog enhances spheroid formation in vitro and significantly increases new tumor formation in vivo. Furthermore, CD133-positive lung cancer cells isolated from patients exhibited a high level of Oct4 and ABCG2, and displayed a clear resistance to chemotherapy and radiotherapy (13). Conversely, the attenuation of Oct4 and Nanog expression levels using RNA interference in CSCs led to the loss of the ability to form spheroids and enhanced the sensitivity of these cells to chemotherapy $(12,14)$. 
Cumulative research has identified the mechanism regulating cancer stemness properties. Recently, the Akt pathway was demonstrated to be an upstream signaling pathway of Oct4, which is linked to the CSC-like phenotype (15). The phosphorylation of Akt promotes stemness through the upregulation of both the mRNA and protein levels of Oct4 and Nanog $(15,16)$. Akt-positive cancers that express CSC markers can establish colonies in vitro and in vivo $(17,18)$. In contrast, Akt-knockdown experiments using RNA silencing resulted in an extensive suppression of Oct 4 as well as an impeded stemness behavior (19). The alteration of both Akt activity and expression may disrupt Oct4 and Nanog functions, and consequently, the CSC properties of cancer.

Several strategies to the suppression of the CSC mechanism have been intensively emphasized. Natural substances from plant sources, including vanillin, have gained increased interest in an alternative therapy due to their various pharmacological activities (20). Vanillin, 4-hydroxy-3-methoxybenzaldehyde (Fig. 1), is the main active ingredient found in the Vanilla planifolia seed. It is widely used as a flavoring agent in many products including food and cosmetics (21). Previous reports have demonstrated several biological activities of vanillin such as antimicrobial, hypotriglyceridemic, anti-inflammatory and antimutagenic activities in rodents and humans (22-24). Vanillin has been shown to inhibit cancer invasion and migration through the reduction of matrix metalloprotease activity and downregulation of nuclear factor- $\kappa \mathrm{B}$ in hepatocellular carcinoma cells (25). Vanillin could also attenuate the formation of lamellipodia and angiogenesis in lung cancer via the suppression of PI3K activity and inducing the apoptosis of various cancer types, such as human cervical cancer and breast cancer (26-28). However, the pharmacological effect of vanillin and its mechanism on CSC-like properties in lung cancer has not been elucidated. In this study, we investigated the effects of vanillin on the CSC phenotypes in the non-small cell lung cancer (NSCLC) NCI-H460 cell line. We herein demonstrated for the first time that vanillin can suppress the stemness behavior of NCI-H460 cells, including spheroid formation, with a reduction in CSC markers. Furthermore, our data showed that Akt is the primary target of the vanillinattenuating CSC behavior, suggesting that vanillin exhibits potential for further anticancer development.

\section{Materials and methods}

Cells and culture conditions. The human NSCLC cell line NCI-H460 was purchased from the American Type Culture Collection, ATCC (Manassas, VA, USA) and was cultured as monolayers in Roswell Park Memorial Institute-1640 medium (RPMI) supplemented with $10 \%$ fetal bovine serum (FBS), $2 \mathrm{mM} \mathrm{L}$-glutamine and $100 \mathrm{U} / \mathrm{ml}$ penicillin and streptomycin. Cell cultures were incubated at $37^{\circ} \mathrm{C}$ in a humidified incubator filled with $5 \% \mathrm{CO}_{2}$. Cells were subcultured routinely with $0.25 \%(\mathrm{w} / \mathrm{v})$ trypsin in $0.53 \mathrm{mM}$ ethylenediamine tetraacetic acid (EDTA) and were seeded according to the manufacturer's instructions at $\sim 70 \%$ confluence.

Reagents and antibodies. Vanillin (Fig. 1), as USP-secondary standard purity grade ( $>99.0 \%$ purity) was purchased from Sigma-Aldrich (St. Louis, MO, USA). The vanillin stock solution was freshly diluted with RPMI medium, and the treatment solution was prepared by dilution of the stock solution with culture media to the desired concentrations. Cell culture media were also used as the control solvent for the experiments. Glutamate, penicillin-streptomycin antibiotics, and phosphate-buffered saline (PBS) were purchased from Gibco (Grand Island, NY, USA). Methanol, dimethyl sulfoxide (DMSO) and mouse monoclonal antibodies to Oct4 $(1: 1,000)$ and ubiquitin $(1: 1,000)$ were purchased from SigmaAldrich. Rabbit monoclonal antibodies to ABCG2 (1:1,000), $\beta$-catenin $(1: 1,000)$, Nanog $(1: 1,000)$ and phosphorylated Akt (P-Akt, $(1: 1,000)$ in Ser473 and Thr308 were from Cell Signaling Technology, Inc. (MA, USA). A goat monoclonal antibody against ALDH1A1 $(1: 1,000)$ was purchased from Santa Cruz Biotechnology (Santa Cruz, CA, USA), and rabbit monoclonal antibody against CD133 $(1: 1,000)$ was purchased from United States Biological (MA, USA).

Cell viability and cell proliferation assays. Cell viability and proliferation assays were performed using the surrogate 3-(4,5-dimethylthiazol-2-yl)-2,5-diphenyltetrazolium bromide (MTT) colorimetric assay. Briefly, NCI-H460 cells were seeded onto 96-well plates at 10,000 cells/well and 2,500 cells/well for the cell viability and proliferation assays, respectively. After cell attachment, various concentrations of vanillin $(0-400 \mu \mathrm{M})$ were added for $24 \mathrm{~h}$ for the cell viability assay. Cells pretreated with the same concentration of vanillin for 1 and 3 days were subcultured and incubated for 24, 48 and $72 \mathrm{~h}$ for the cell proliferation assays. At the end of each incubation time, the medium was removed and replaced with MTT solution (Life Technologies, Carlsbad, CA, USA) and incubated for $3 \mathrm{~h}$ at $37^{\circ} \mathrm{C}$. The MTT solution was then substituted with $100 \mu 1$ of DMSO to dissolve the formazan crystals, and then the absorbance was measured at $570 \mathrm{~nm}$ using a microplate reader. The absorbance was calculated and represented as the $\%$ viability and $\%$ relative proliferation, respectively, compared with the untreated (control) cells that were set at $100 \%$.

Determination of apoptotic and necrotic cell death. Hoechst 33342 and propidium iodide (PI) (Sigma-Aldrich) were used to stain the nuclei to identify necrotic and apoptotic cell death, respectively. Cells were treated with vanillin for $24 \mathrm{~h}$ and then were washed with PBS, followed by incubation with either $5 \mu \mathrm{M}$ PI or $10 \mu \mathrm{M}$ Hoechst 33342 at $37^{\circ} \mathrm{C}$ for $30 \mathrm{~min}$. Cells were visualized and captured under a fluorescence microscope at $\mathrm{x} 10$ magnification (Olympus IX5; 10X with DP70 digital camera system; Olympus, Tokyo, Japan). PI-positive necrotic cells and nuclear condensation of apoptotic cells were scored and reported as the $\%$ of all cells viewed.

Anchorage-independent growth assay. The NCI-H460 cells were pretreated with vanillin $(0-50 \mu \mathrm{M})$ for 1 and 3 days before being subjected to the soft agar colony-formation assay to determine the anchorage-independent growth property of cancer stemness. Soft agar was prepared using a combination of complete media and 1\% (w/v) agarose at a 1:1 ratio. This mixture was allowed to solidify in 24-well plates as a bottom layer. Next, pretreated cells suspended in RPMI complete 


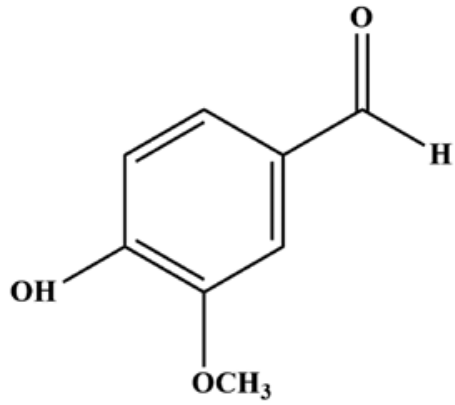

Figure 1. Chemical structure of vanillin (4-hydroxy-3-methoxybenzaldehyde).

media were mixed with $0.3 \%(\mathrm{w} / \mathrm{v})$ agarose, added onto the prepared bottom layer and then incubated at $37^{\circ} \mathrm{C}$. Further complete media were applied every 2 days to prevent the soft agar drying. After 2 weeks, the colony was examined under a phase-contrast microscope at $\mathrm{x} 4$ magnification (Olympus IX5; $4 \mathrm{X}$ with DP70 digital camera system; Olympus). The relative colony number and size were analyzed compared with those of the control group.

Spheroid formation assay. Vanillin-pretreated cells at a cell density of 2,500 cells/well were cultured in 24-well ultralow attachment plates in RPMI serum-free medium for 7 days. Next, the spheroids were disaggregated by trypsinization, resuspended in RPMI serum-free medium as a single cell suspension and then cultured onto 24-well ultralow attachment plates. After an additional 14 days, the presence of secondary spheroids was investigated by phase-contrast microscopy at x4 magnification (Olympus 1X51 with DP70). The relative spheroid number and size were analyzed compared with those of the control group.

Western blot analysis. Cells were lysed using lysis buffer containing $20 \mathrm{mM}$ Tris- $\mathrm{HCl}(\mathrm{pH} 7.5), 150 \mathrm{mM} \mathrm{NaCl}, 1 \%$ Triton $\mathrm{X}-100,1 \mathrm{mM} \mathrm{Na} \mathrm{VO}_{4}, 10 \%$ glycerol, $50 \mathrm{mM} \mathrm{NaF}, 100 \mathrm{mM}$ phenylmethylsulfonyl fluoride (PMSF; Sigma-Aldrich), and a protease inhibitor cocktail (Merck Millipore, MA, USA), sonicated and incubated on an ice bath for $45 \mathrm{~min}$. The protein content was measured using the BCA protein assay kit (Pierce ${ }^{\mathrm{TM}}$ Thermo Fisher Scientific Inc., IL, USA). An equal amount of denatured protein was separated by electrophoresis $[10 \%(\mathrm{w} / \mathrm{v})$ acrylamide resolving gel] and transferred to a $0.45-\mu \mathrm{m}$ nitrocellulose membrane (Bio-Rad, Hercules, CA, USA). Each membrane was blocked with $5 \%$ (w/v) nonfat-milk in Tris-buffered saline solution containing $1 \%(\mathrm{v} / \mathrm{v})$ Tween-20 (TBST) for at least $30 \mathrm{~min}$ and then incubated with the indicated primary antibody at $4^{\circ} \mathrm{C}$ overnight. Thereafter, the membranes were washed three times with TBST and then incubated with secondary antibody at room temperature for $2 \mathrm{~h}$. The antigen-antibody complexes were detected, after washing with TBST as above, using chemiluminescent solution (Pierce Biotechnology) and were exposed to film (Carestream Health, Inc., Rochester, NY, USA). The densitometry of the target protein was measured using the NIH ImageJ program and quantified as the relative expression level to that of the control group.
Immunoprecipitation assay. Protein interaction was examined by immunoprecipitation. Cells were incubated with $10 \mu \mathrm{M}$ lactacystin for $1 \mathrm{~h}$ prior to treatment with vanillin to inhibit proteasome function while preserving the ubiquitinprotein complex. Treated cells were collected and lysed in TMN buffer $(50 \mathrm{mM}$ Tris- $\mathrm{HCl} \mathrm{pH} 7.5,140 \mathrm{mM} \mathrm{NaCl}$ and $0.5 \mathrm{mM} \mathrm{MgCl}_{2}$ ) containing $10 \%$ glycerol, a protease inhibitor cocktail, $1 \%$ nonylphenylpolyethylene glycol (NP-40) and $1 \%$ PMSF for $30 \mathrm{~min}$, followed by centrifugation at $12,000 \mathrm{rpm}$ at $4^{\circ} \mathrm{C}$ for $15 \mathrm{~min}$. The supernatants were blocked with protein $\mathrm{G}$ agarose beads (GE Healthcare, Little Chalfont, $\mathrm{UK}$ ) to remove non-specific binding. After centrifugation at $3,000 \mathrm{rpm}$ at $4^{\circ} \mathrm{C}$ for $5 \mathrm{~min}$, the protein contents were measured. The supernatants were collected and stored at $4^{\circ} \mathrm{C}$ as an input for immunoblotting where $300 \mu \mathrm{g}$ of protein was incubated with anti-Akt antibody at $4^{\circ} \mathrm{C}$ overnight and then incubated with protein $\mathrm{G}$ agarose beads for $2 \mathrm{~h}$ at $4^{\circ} \mathrm{C}$. The immunoprecipitates were collected, washed with TMN buffer and resuspended in $30 \mu \mathrm{l}$ of $2 \mathrm{X}$ SDS sample buffer. The samples were boiled at $95^{\circ} \mathrm{C}$ for $5 \mathrm{~min}$ and then were subjected to western blot analysis using antibodies against ubiquitin.

Statistical analysis. The data were collected from at least four independent experiments, normalized by the control groups and presented as the means \pm standard deviation (SD). The significant difference among the groups was analyzed using one-way ANOVA followed by the post hoc test. Statistical analysis was performed using SPSS software (IBM Inc., NY, USA) and statistical significance was accepted at the $\mathrm{p}<0.05$ level.

\section{Results}

Cytotoxicity and anti-proliferative effect of vanillin on NCI-H460 cells. To diminish the interference of the cytotoxic effect of vanillin on cancer stemness, a non-toxic concentration of vanillin was used on the NCI-H460 cells, as determined by the cytotoxicity assay. Cells were treated with various concentrations of vanillin for $24 \mathrm{~h}$ and were then subjected to the MTT cell viability assay. Fig. 2A demonstrates that $200 \mu \mathrm{M}$ vanillin caused a significant $(\mathrm{p}=0.003)$ mortality with $\sim 30 \%$ cell death, whereas at a concentration of $<100 \mu \mathrm{M}$ at least $80 \%$ viable cells remained. To confirm the cell death mechanism, cells were similarly treated with vanillin for $24 \mathrm{~h}$ and then were incubated with either Hoechst 33342 or PI, where apoptotic nuclei and necrotic bodies were clearly observed in the cells treated with a high $(200 \mu \mathrm{M})$ dose of vanillin (Fig. $2 \mathrm{~B}$ and $\mathrm{C}$ ). This result is consistent with the cell viability testing, revealing that vanillin at concentrations of $<100 \mu \mathrm{M}$ are non-toxic to NCI-H460 cells, so these doses were used for subsequent experiments.

The effect of vanillin on NCI-H460 cell proliferation was also investigated. The cells were pre-treated with vanillin for 1 and 3 days, prior to measuring their proliferation after a further 24,48 and $72 \mathrm{~h}$. The proliferation of the cells pretreated with $100 \mu \mathrm{M}$ vanillin for 3 days was significantly reduced as early as $24 \mathrm{~h}$, whereas lower doses $(<100 \mu \mathrm{M})$ had no significant effect at any detection time (Fig. 2E). Furthermore, pretreatment with vanillin for 1 day showed non-detectable 
A

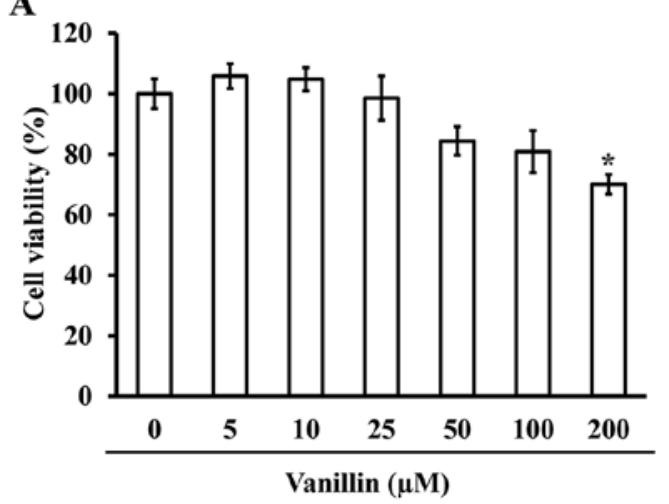

C

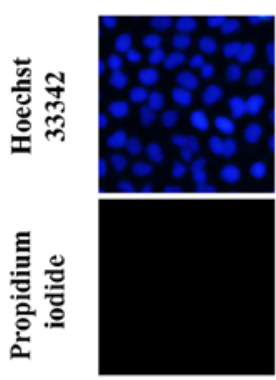

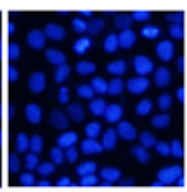

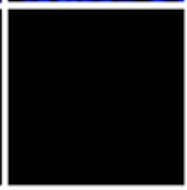

5

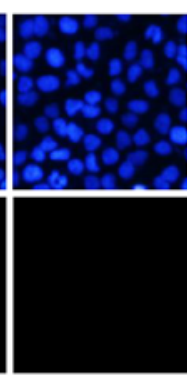

10
B

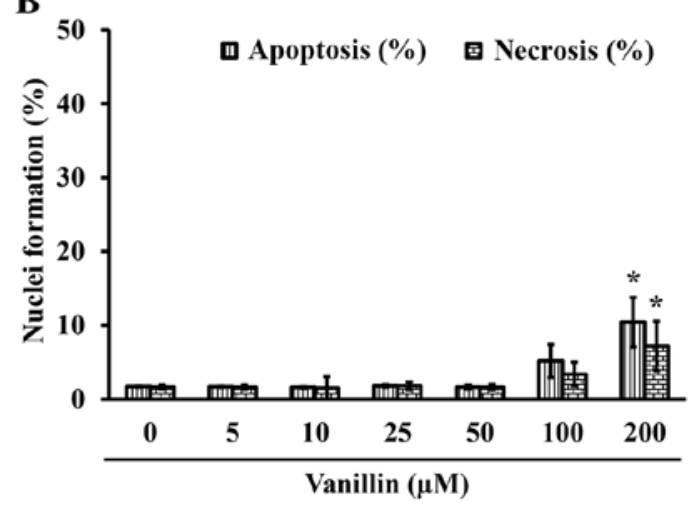

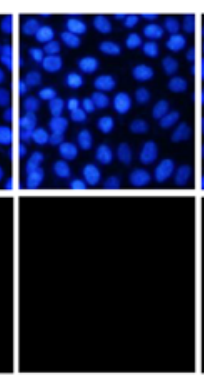

25

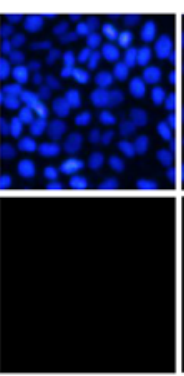

50

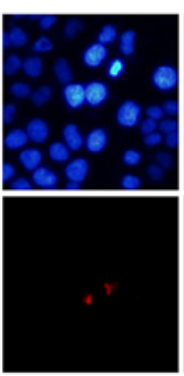

100

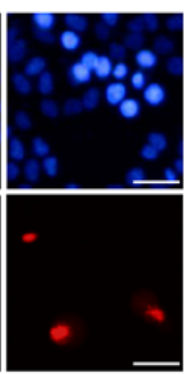

200
D

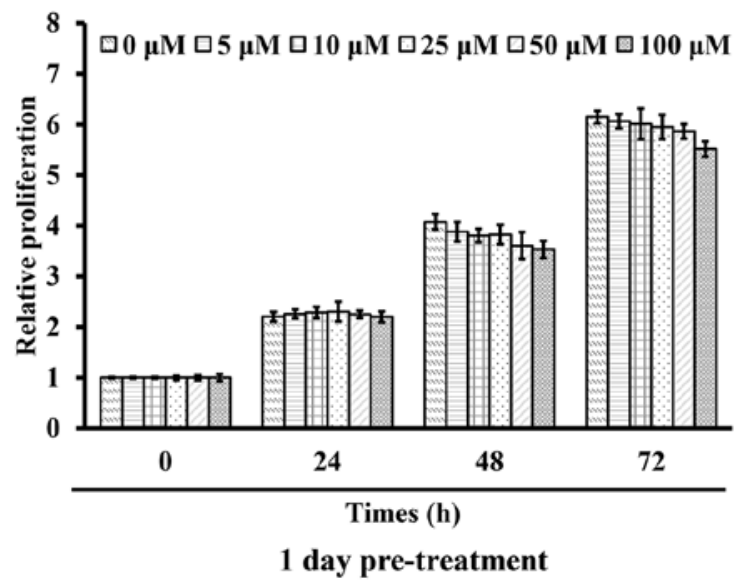

$\mathbf{E}$

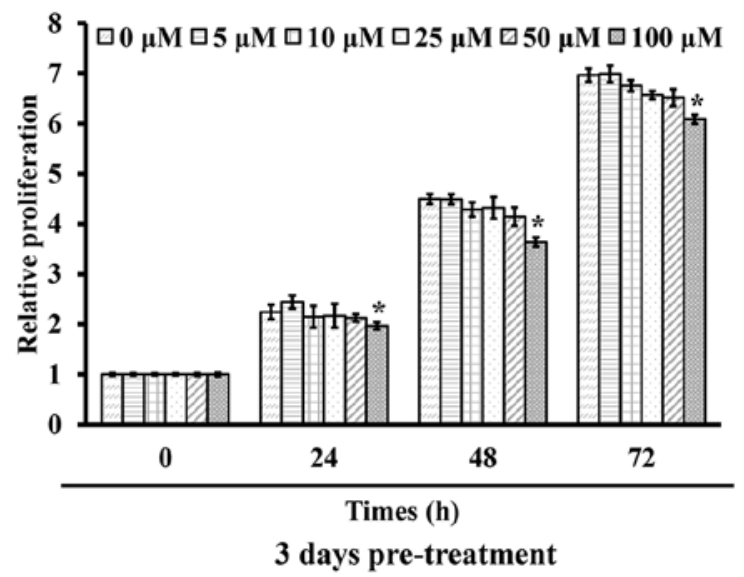

Figure 2. Cytotoxic and anti-proliferative effects of vanillin in NCI-H460 cells. (A) NCI-H460 cells were treated with vanillin at various concentrations $(0-200 \mu \mathrm{M})$ for $24 \mathrm{~h}$, and cell viability was measured by the MTT assay. (B and C) Apoptotic and necrotic cells were determined by staining with Hoechst 33342 $(10 \mu \mathrm{M})$ and propidium iodide $(5 \mu \mathrm{M})$, and examined under a fluorescence microscope (scale bar, $100 \mu \mathrm{m})$. Apoptotic nuclei and PI-positive necrotic cells were counted and reported as the percentage of the total cell number. NCI-H460 cells were pretreated with vanillin $(0-100 \mu \mathrm{M})$ for 1 day $(\mathrm{D})$ or 3 days $(\mathrm{E})$. The proliferation of the cells was evaluated by the MTT assay for 24, 48 and $72 \mathrm{~h}$, reported as the relative value to that of the control group at time $0 \mathrm{~h}$. Data are presented as the means \pm SD from at least four independent experiments. *p-value $<0.05$ versus the non-treated group.

changes compared with that in the control group (Fig. 2D). These results indicated that a low dose of vanillin $(0-50 \mu \mathrm{M})$ neither induced cell death nor inhibited cell proliferation in the NCI-H460 cells. Cell growth and survival in the absence of extracellular matrix is one of the crucial behaviors of the cancer stem-like phenotype. Thus, to avoid any anti-proliferative effect of vanillin on cancer stem cell growth, vanillin doses that showed no such effect on NCI-H460 cells under the attachment condition were then used for the cancer stem-like phenotype characterization.
Inhibitory effect of vanillin on the anchorage-independent growth and spheroid formation of NCI-H460 cells. Because self-renewal and tumorigenicity are distinctive behaviors for the cancer stem-like phenotype, anchorage-independent growth and spheroid formation have been used to characterize these features. To investigate the suppressive effect of vanillin on colony and spheroid formation, NCI-H460 cells were pretreated with vanillin $(0-50 \mu \mathrm{M})$ for 1 and 3 days, followed by examination of their anchorage-independent growth and spheroid formation. Fig. 3A shows representative images in 
A

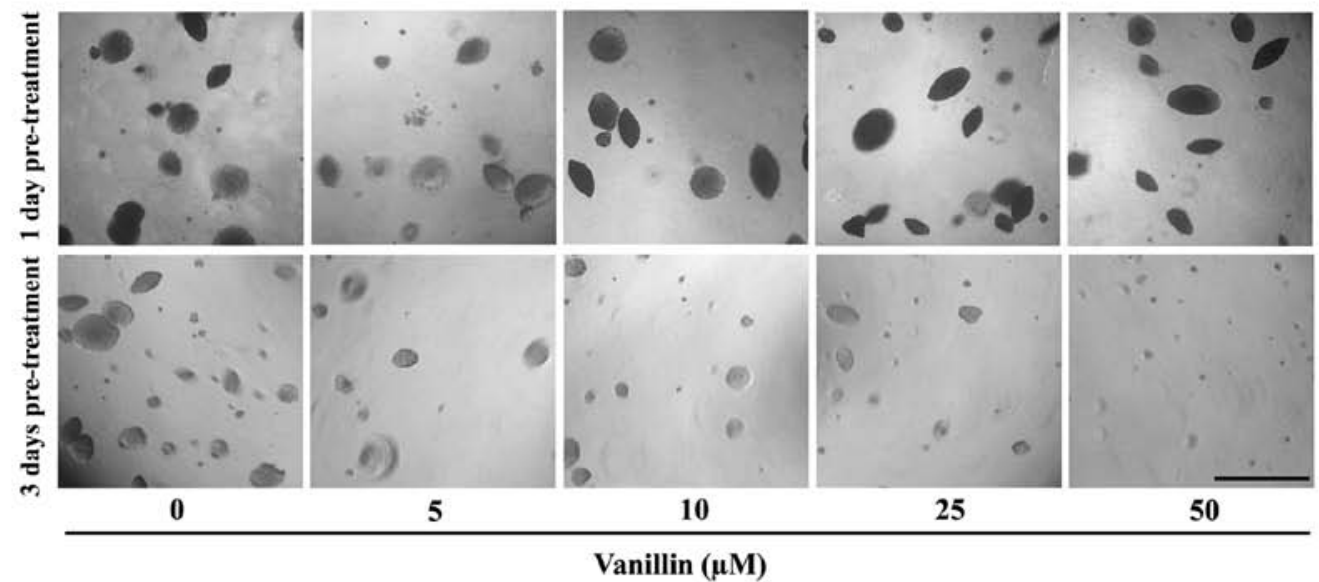

B

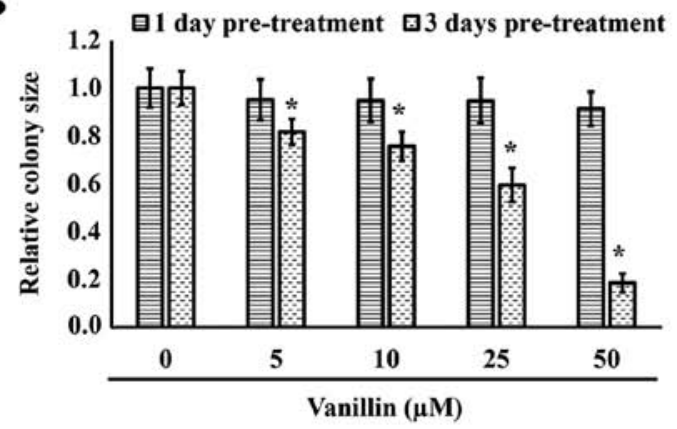

C

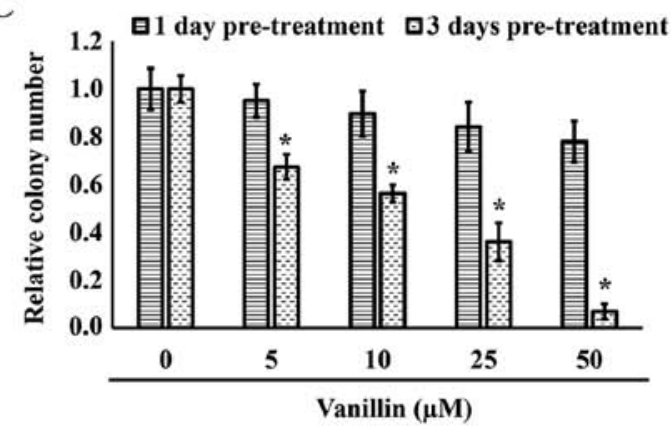

D

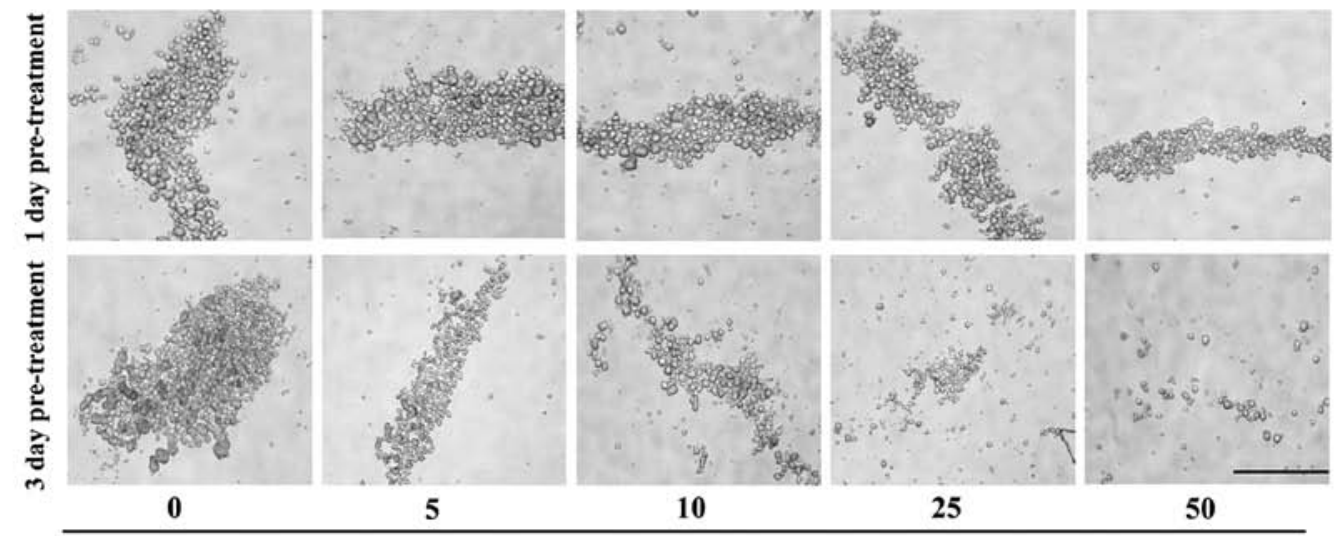

Vanillin $(\mu \mathbf{M})$

E

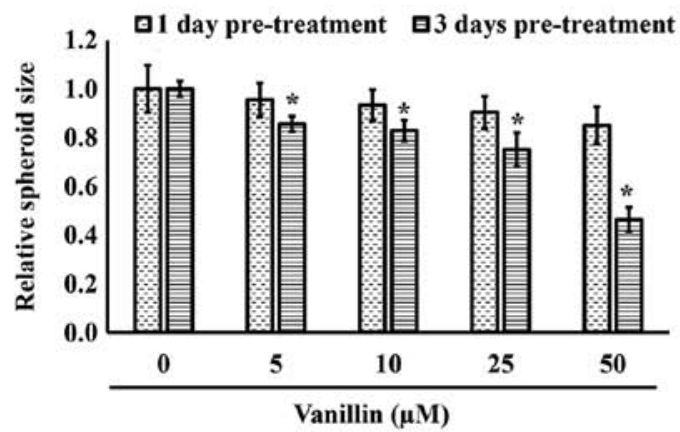

F

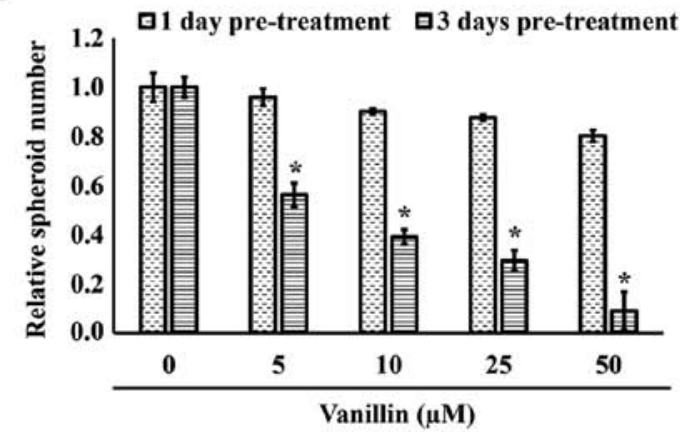

Figure 3. Vanillin suppresses anchorage-independent growth and spheroid formation of NCI-H460 cells. (A) NCI-H460 cells were pre-treated with vanillin $(0-50 \mu \mathrm{M})$ for 1 and 3 days. Cells were then detached and cultured on soft agar as described in Materials and methods. Colonies were captured at 14 days after culture (scale bar, $200 \mu \mathrm{m}$ ). (B) The colony size and (C) number were measured and presented as the relative value to the control cells under each condition. (D) H460 cells were similarly pre-treated with vanillin $(0-50 \mu \mathrm{M})$ for 1 and 3 days. Cells were detached and subjected to the spheroid formation assay. After 7 days, primary spheroids were dissociated and cultured on ultra-low cell culture plates for 14 days. The secondary spheroids were imaged (scale bar, $200 \mu \mathrm{m}$ ). (E) The spheroid size and (F) number were analyzed and presented as the relative value to the control cells of each condition. Data are presented as the means \pm SD from at least four independent experiments. * p-value $<0.05$ versus the non-treated group. 
A
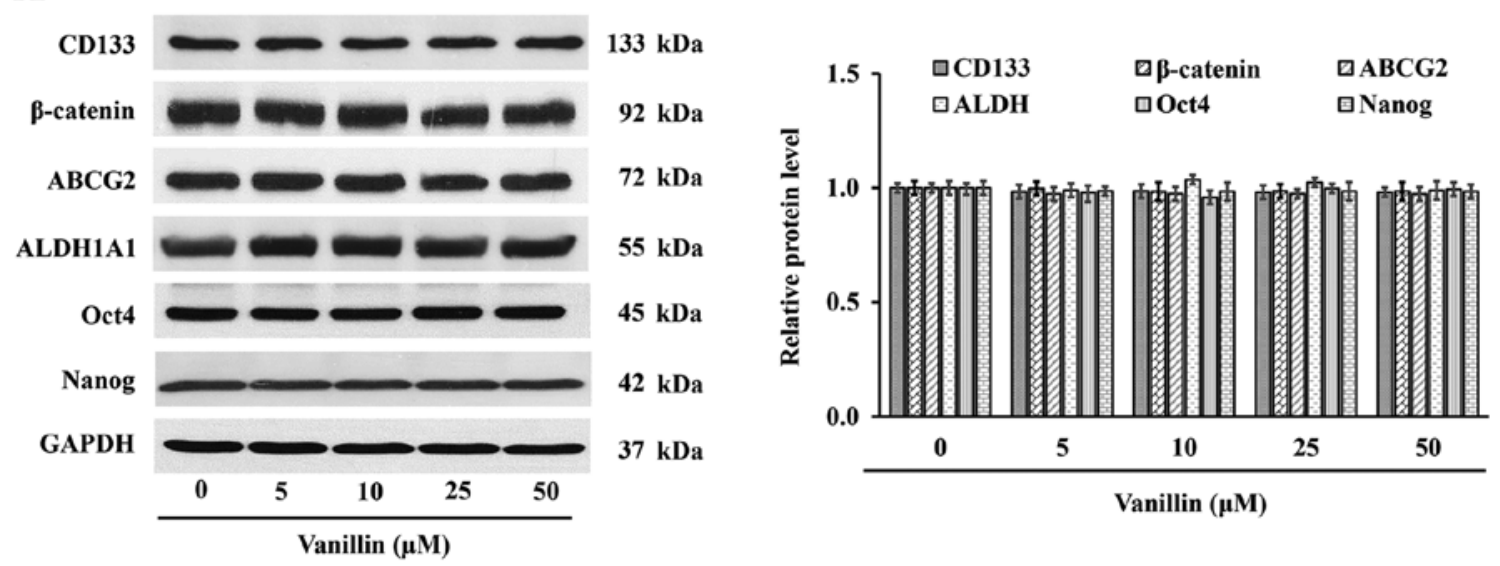

B
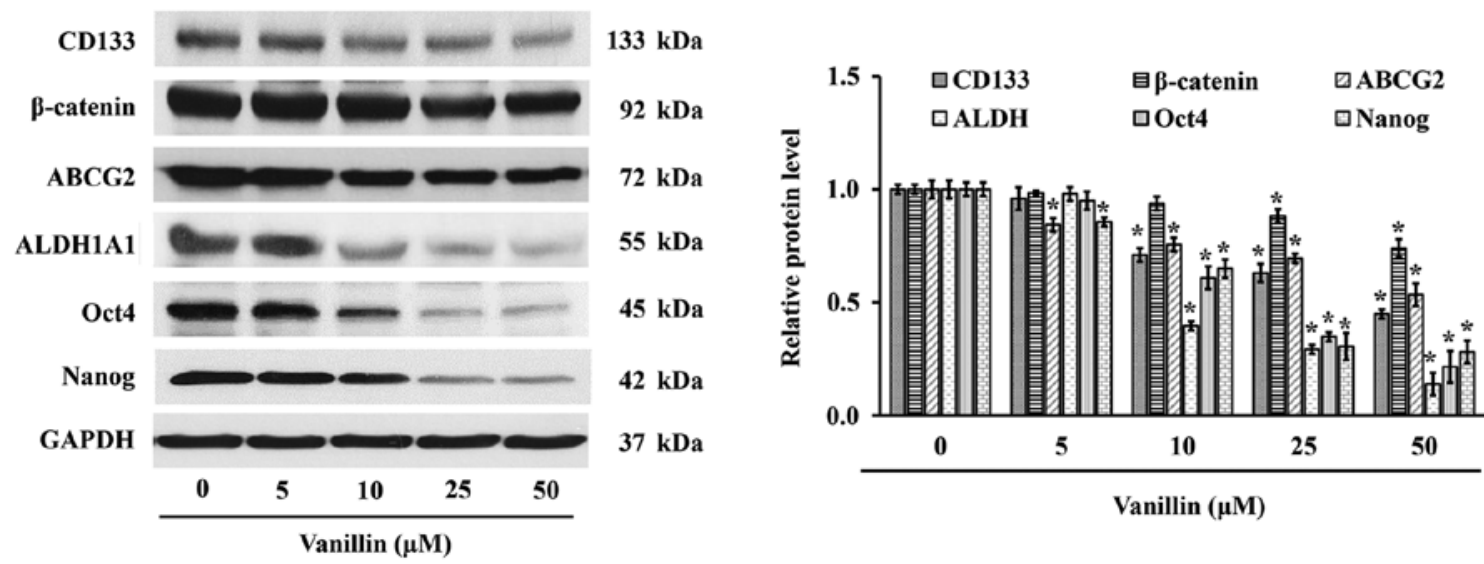

Figure 4. Vanillin downregulates lung cancer stemness markers. NCI-H460 cells were treated with vanillin (0-50 $\mu \mathrm{M})$ for 1 day (A) or 3 days (B), and the expression levels of CD133, $\beta$-catenin, ABCG2, ALDH1A1, Oct4 and Nanog, were examined by western blotting using specific antibodies. The blots were reprobed with antibody against GAPDH to ensure equal loading and quantified densitometrically using ImageJ. Data are presented as the means \pm SD from at least four independent experiments. ${ }^{*}$-value $<0.05$ versus the non-treated group.

which both the colony size and number of cells pretreated with vanillin for 1 day were not different from those of untreated control cells. However, a significant and vanillin dosedependent reduction in the cell size and number was observed when pre-incubated with vanillin for 3 days (Fig. 3B and C). Approximately 80 and $90 \%$ reduction in the colony size and number, respectively, were observed in the NCI-H460 cells pretreated with $50 \mu \mathrm{M}$ vanillin for 3 days $(\mathrm{p}=0.027)$.

The effect of vanillin on the self-renewal property was evaluated by the spheroid formation assay. Primary spheroids, consisting of several types of cells, including progenitors, mature cells and stem cells (29), were first initiated for 7 days and then dissociated to single cells. The single cells were allowed to grow under detachment conditions to form secondary spheroids over 14 days, reflecting the pluripotency of CSCs. Interestingly, pretreatment with vanillin for 3 days markedly attenuated the number of secondary spheres formed under detachment conditions, with only $\sim 0.2$-fold of the number of sphere remaining after pretreatment with $50 \mu \mathrm{M}$ vanillin for 3 days $(\mathrm{p}=0.022)$. In contrast, this effect was not found with a 1-day pretreatment with vanillin (Fig. 3D-F). These results suggest that vanillin can abolish the cancer stemlike phenotype of CSCs, in terms of both spheroid formation and anchorage-independent growth.
Vanillin downregulates stemness markers in NCI-H460 cells. Cancer stem cell markers are differentially expressed in different types of cancer, with CD133, ABCG2 and ALDH1A1 being distinctly expressed in lung cancer stem cells (3). Given the inhibitory effect of vanillin on the CSC phenotype, its effect on stemness cell markers was then evaluated in the NCI-H460 cells. NCI-H460 cells were incubated with vanillin $(0-50 \mu \mathrm{M})$ for 1 and 3 days, and then the expression of CSCs markers was determined. Based on western blot analysis (Fig. 4), CSC protein marker expression was not significantly changed in response to the treatment with vanillin for 1 day $(50 \mu \mathrm{M}$, $\mathrm{p}=0.124)$. However, the level of CSC markers, including those of CD133, ABCG2 and ALDH1A1, were markedly attenuated in a dose-dependent manner after treatment with vanillin for 3 days (Fig. 4B). Quantitative analysis demonstrated that a reduction in the expression level of these proteins was observed in cells treated with vanillin for 3 days at concentrations as low as $10 \mu \mathrm{M}(\mathrm{p}=0.021)$. Thus, vanillin suppresses not only the CSC phenotype but also CSC markers in NCI-H460 cells.

Vanillin suppression of Nanog and Oct4 expression is mediated by an Akt-dependent mechanism. The CSC phenotypes include not only an elevated expression of stemness markers, but also high levels of the related transcription factors, 
A

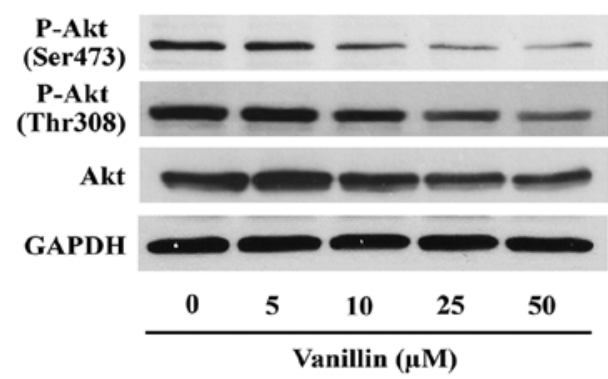

$60 \mathrm{kDa}$

$60 \mathrm{kDa}$

$60 \mathrm{kDa}$

37 kDa

B

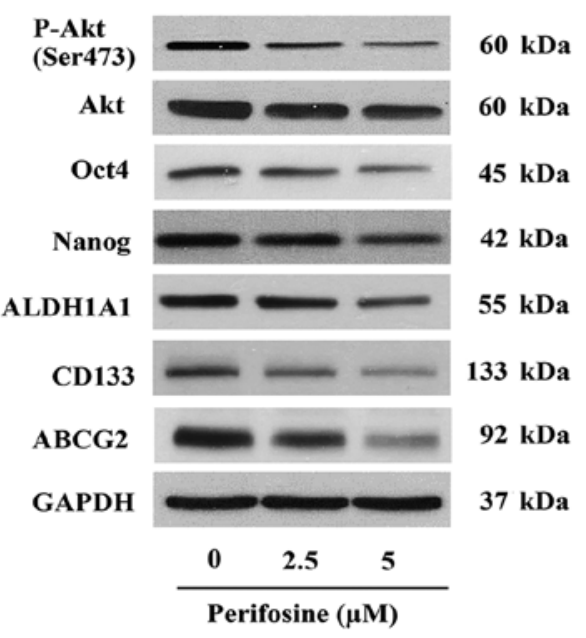

C

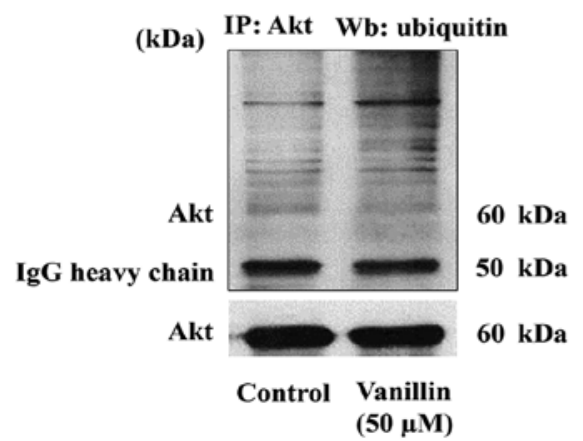

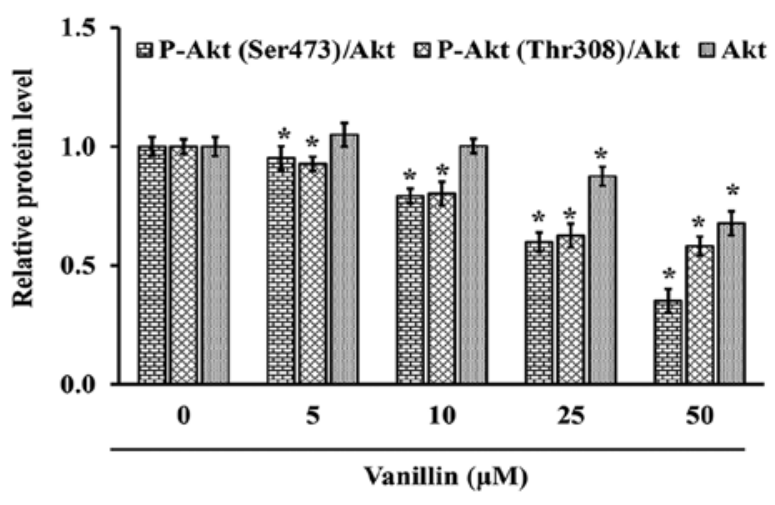
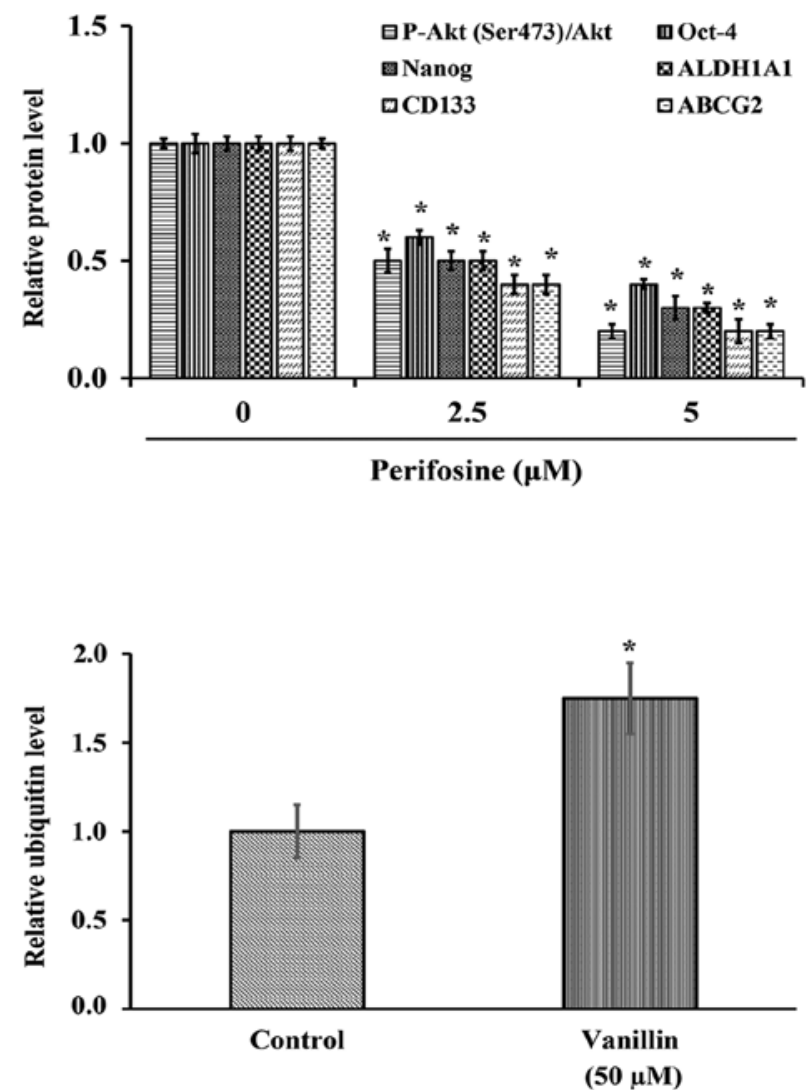

Figure 5. Vanillin mediates Akt degradation via a ubiquitin-proteasomal mechanism. (A) NCI-H40 cells were similarly treated with vanillin (0-50 $\mu \mathrm{M})$ for 3 days, and the expression levels of Akt and its activated form (P-Akt, Ser 473 and Thr308) were determined by western blotting. (B) NCI-H460 cells were treated with perifosine $(0-2.5 \mu \mathrm{M})$ for 3 days, and the protein expression was evaluated by western blot analysis. The blots were reprobed with antibody against GAPDH to ensure equal loading. Immunoblot signals were quantified using Image $J$ and presented as the relative protein expression level normalized to the control group. (C) NCI-H460 cells were pre-treated with $10 \mu \mathrm{M}$ lactacystin (Lac) prior to $50 \mu \mathrm{M}$ vanillin for $3 \mathrm{~h}$. The Akt was immunoprecipitated using an antibody against Akt and protein $\mathrm{G}$ agarose beads. The immunocomplex was analyzed by immunoblotting using antibody against ubiquitin. Data are presented as the mean $\pm \mathrm{SD}$, derived from at least four independent experiments. * p-value $<0.05$ versus the non-treated group.

including Nanog and Oct4 (10-12) that endow a self-renewal property to the cells (30). To assess whether the negative regulation of CSCs properties by vanillin involved these transcription factors, NCI-H460 cells were treated with various concentrations of vanillin for 1 and 3 days, and then protein expression levels of Oct4 and Nanog were evaluated. As shown in Fig. 4B, the Oct4 and Nanog protein expression levels were significantly decreased in the cells treated with vanillin for 3 days, but not in the cells treated for 1 day (Fig. 4A). These results illustrate a good correlation with the other stemness phenotypes (Fig. 3 and 4), demonstrated by their suppression after treatment with vanillin for 3 days.

Because the expression levels of Nanog and Oct4, which contribute to the stemness behavior, are regulated directly by Akt (15), whether vanillin modulates Akt protein expression levels or its activity in terms of P-Akt expression was evaluated next. NCI-H460 cells were treated with vanillin for 3 days prior to determination of the Akt and P-Akt expression levels. Western blot analysis showed that the level of P-Akt (Ser473 and Thr308) or active Akt, was decreased (Fig. 5A), 


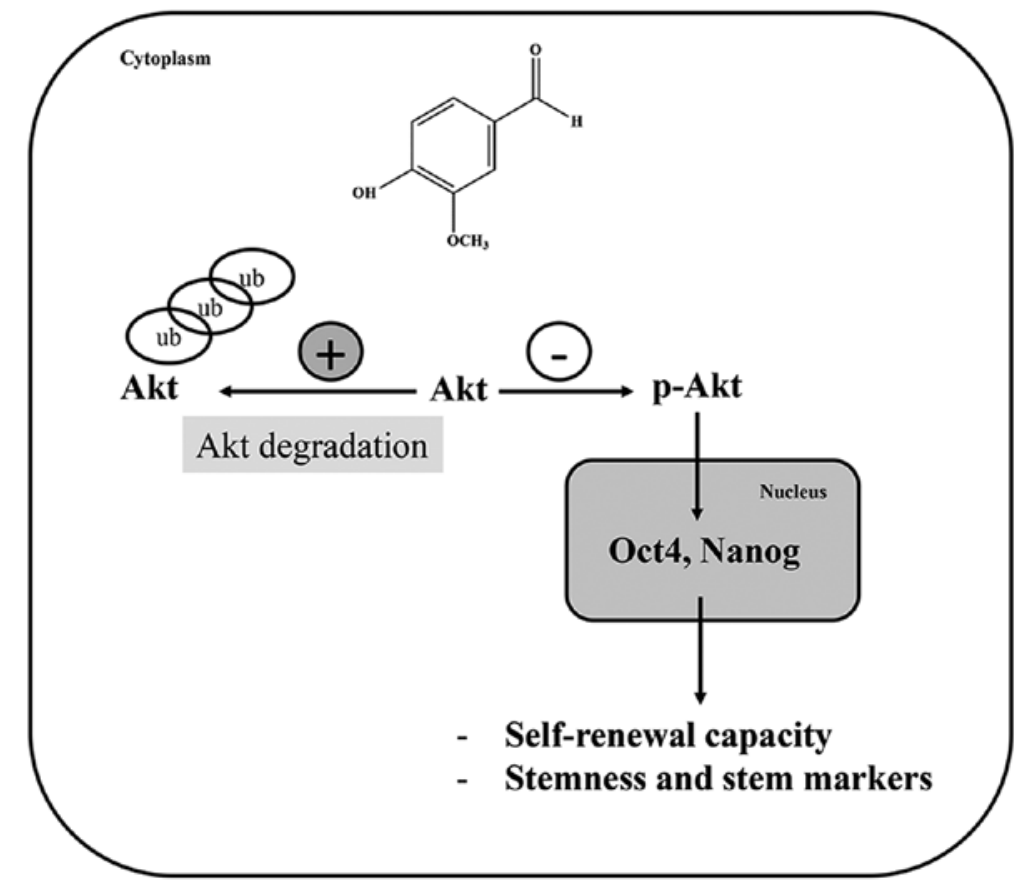

Figure 6. Schematic overview of the effect of vanillin on lung cancer stem-like phenotypes and its related pathway. Vanillin inhibits Akt activation and its expression by mediating Akt degradation through the ubiquitin-proteasomal pathway, downregulates the pluripotent transcription factors Oct 4 and Nanog, and consequently suppresses self-renewal properties and cancer stem markers.

suggesting that the reduced CSCs phenotypes may result from an Akt-dependent mechanism. To verify whether the reduction of P-Akt by vanillin is a result of the suppression of P-Akt or total Akt expression levels, the total Akt expression level was also investigated. As shown in Fig. 5A, the total Akt level was clearly downregulated in a similar pattern. Densitometry analysis of P-Akt relative to total Akt was then analyzed to confirm the hypothesis that vanillin interferes with the Akt expression level. The quantitative results demonstrated that the ratio of P-Akt over its parental form are also changed, indicating the reduction of Akt expression may be, at least in part, a mechanism by which vanillin suppresses Akt activity.

To confirm the above finding that the downregulation of Nanog and Oct4 by vanillin is by an Akt-dependent pathway, perifosine (1,1-dimethylpiperidinium-4-yl octadecyl phosphate), an Akt inhibitor, was used as a positive control. H460 cells were treated with perifosine $(0-5 \mu \mathrm{M})$ for 3 days, and the mentioned proteins were observed by western blotting as before. Interestingly, inactivation of Akt by perifosine caused a reduction of its downstream signaling, including Oct4 and Nanog (Fig. 5B), similar to that with vanillin (Fig. 4B). The CSC markers CD133, ABCG2 and ALDH1A1 were also downregulated corresponding to the suppression of $\mathrm{Akt}$ activity. Although the vanillin-blocked Akt activation occurs partly through downregulating the parental form, the total effect is similar to that by perifosine. These data indicated the Akt function that promotes cancer stemness property via Oct4 and Nanog, which was conversely inhibited by vanillin.

Vanillin mediates Akt degradation through the ubiquitinproteasomal pathway. Emerging evidence has indicated that the existence of Akt is mainly governed by ubiquitin-proteasomal degradation via E3 ligase $(31,32)$. The reduction of Akt by the enhancement of this mechanism results in the interference of its downstream signaling mediators, including Oct4 and Nanog $(11,15,16,33,34)$. Accordingly, we next examined whether downregulation of Akt by vanillin occurred through the ubiquitin proteasomal pathway. Protein degradation by this pathway requires the protein to bind with ubiquitin prior to recognition by the proteasome (35). NCI-H460 cells were pretreated with $10 \mu \mathrm{M}$ lactacystin (Lac), a proteasomal inhibitor, prior to vanillin treatment $(50 \mu \mathrm{M})$ for $3 \mathrm{~h}$, and the presence of Akt-ubiquitin complex was determined by immunoprecipitation. Fig. 5C shows that the level of the Akt-ubiquitin interaction was markedly increased $\sim 2$-fold in the vanillintreated group, which indicated that suppression of CSCs by vanillin may be a consequence of vanillin promoting Akt degradation through the ubiquitin-proteasomal pathway.

\section{Discussion}

Taken together, cancers are one of the most common non-accident related cause of deaths among human populations, but the successful rate of treatment is low due to the resistance to chemotherapy treatment, metastasis and the self-renewal properties of cancer cells. It has been reported that these aggressive behaviors are driven by CSCs (2), which are a small population found within tumors, especially in metastatic cancers (3). These CSCs exhibit an overexpression of specific markers such as CD133, ALDH1A1 and ABCG2 (2,36), and related proteins such as Akt and mTOR (37). Recently, research into drug discovery and development for cancer therapy has focused on exploring new natural compounds that target CSCs and related pathways. Several reports have suggested that many natural substances, such as curcumin, resveratrol and pomegranate extract, have the ability to inhibit CSCs (38-40). 
Herein, we report for the first time that vanillin, an active component in Vanilla planifolia, suppresses CSCs in term of both their phenotype and related molecular mechanisms. A non-cytotoxic concentration of vanillin $(50 \mu \mathrm{M})$ attenuated spheroid formation and anchorage-independent growth, which are the two prominent characteristics of CSCs (Fig. 3). The inhibitory effects of vanillin were clearly observed after treatment for 3 days, suggesting that in the early phase of treatment, a compensation mechanism by other kinase proteins, such as mitogen activated protein kinase (MAPK) or ERK may exist $(41,42)$. Both PI3K/Akt and MAPK/ERK are known to play an important role in the maintenance of cell survival, differentiation and proliferation of cancer $(43,44)$. A recent study reported that epidermal growth factor (EGF) could induce Akt activation through the MEK inhibitor (45). This phenomenon may occur during the 1-day treatment course of vanillin. An alternative possibility is that cellular signaling requires a longer activation time to induce the phenotypic changes. For example, the inhibitory effect of gigantol on CSCs was found only after treatment for at least 2 days (46). The ability of cancer cells to form neurospheres also indicates the pluripotency of CSCs (45), and our finding here demonstrated that vanillin greatly suppresses the in vitro formation of secondary spheroids consisting of NCI-H460 cells (Fig. 3D).

CD133, ALDH1A1 and ABCG2 have been reported to be specific markers in lung CSCs both in vivo and in vitro (47-49). Lung CSCs with CD133+ implanted in mice exhibited a selfrenewal property, chemoresistance and a high tumorigenic capability. Like the in vitro study, NCI-H460 and NCI-A549, which express high levels of ABCG2 and CD133, can form spheroids, but this ability was attenuated after reduction of ABCG2 and CD133 expression (50). We further evaluated the expression of such markers in vanillin-treated cells. Corresponding to the phenotypic changes, vanillin downregulated these lung CSC markers (Fig. 4). As transcription factors, Oct4 and Nanog are frequently found in both CSCs and normal stem cells (49), and are responsible for maintaining the self-renewal and pluripotent properties of CSCs under regulation by the kinase activity of Akt (51). These transcription factors are upregulated in many cancers, especially lung cancer, and the reduction of Oct4 and Nanog expression can directly inhibit CSC phenotypes $(11,30)$. Knockdown of these transcription factors was shown to decrease the proliferation and spheroid formation of cancer cells (15). Supporting our finding, Oct4 and Nanog were extensively decreased in response to vanillin treatment, and so likely contributed to the impedance of neurosphere formation and colony-formation capability of the NCI-H460 cells (Fig. 3).

Evidence has suggested that Akt plays a vital role in cell survival and proliferation (52), and drive cancer cells to CSC-like phenotypes including proliferation, migration and self-renewal properties, through the action of the transcription factors Oct4 and Nanog (16). Blockade of Akt was shown to inhibit the in vitro proliferation of spheroid formation and enhanced Oct 4 degradation (33). In breast cancer, inhibition of PI3K or Akt activity led to pluripotency loss (37). Furthermore, in prostate cancer, the alteration of the PTEN/PI3K/Akt pathway interfered with the CSC phenotype (53). Likewise, in this study, vanillin was found to diminish Akt function and its expression, together with a decreased CSC behavior and marker expression (Fig. 4). As a key protein catabolism pathway, the ubiquitin-proteasomal pathway is known to regulate several cellular signaling molecules, including Akt (54). Targeted proteins for degradation are poly-ubiquitinated by the ubiquitin ligase (E3) of the proteasome prior to recognition by ubiquitin-activating E1 and E2. The results of this study are consistent with the notion that vanillin drives Akt degradation through elevation of the ubiquitinproteasomal pathway (Fig. 5). However, the mechanism that leads to ubiquitinized Akt is still unknown. Recent studies reported that multiple growth factor receptors such as EGFR and insulin-like growth factor 1 receptor, might be possible targets of natural compounds $(55,56)$. Since the ubiquitination-proteasomal degradation of intracellular proteins is modulated by the downstream signaling of these receptors (57-60), it is possible that the mechanism of vanillin action on ubiquitinized Akt might involve vanillin-modulating of these receptors and their signaling pathways. However, the ubiquitin-proteasomal pathway is also regulated by the reactive oxygen species $(61,62)$ and the exogenous compounds, that alter the oxidative status of the cells, affect this degradation pathway $(63,64)$. Since vanillin has been demonstrated to have a dual effect as an oxidative stress scavenging and pro-oxidant activity, depending on the cell type and vanillin concentration (65-67), thus, it is also possible that vanillin may promote Akt degradation through this mechanism.

In conclusion, this study demonstrates that vanillin can suppress the CSC-like phenotype in NCI-H460 cells via the enhancement of the Akt-ubiquitin proteasome degradation pathway, resulting in the downregulation of the transcription factors Oct4 and Nanog (Fig. 6). This finding may provide a new strategy to overcome CSCs in lung cancer.

\section{Acknowledgements}

This study was supported by grant for International Research Integration: Chula Research Scholar, Ratchadaphiseksomphot Endowment Fund, and the 90th Anniversary Chulalongkorn University. The English editing was proofed by The American Journal Expert service.

\section{References}

1. Peters S, Adjei AA, Gridelli C, Reck M, Kerr K and Felip E; ESMO Guidelines Working Group: Metastatic non-small-cell lung cancer (NSCLC): ESMO Clinical Practice Guidelines for diagnosis, treatment and follow-up. Ann Oncol 23 (Suppl 7): vii56-vii64, 2012.

2. Dalerba P, Cho RW and Clarke MF: Cancer stem cells: Models and concepts. Annu Rev Med 58: 267-284, 2007.

3. Medema JP: Cancer stem cells: The challenges ahead. Nat Cell Biol 15: 338-344, 2013.

4. Pallini R, Ricci-Vitiani L, Banna GL, Signore M, Lombardi D, Todaro M, Stassi G, Martini M, Maira G, Larocca LM, et al: Cancer stem cell analysis and clinical outcome in patients with glioblastoma multiforme. Clin Cancer Res 14: 8205-8212, 2008.

5. Lopez-Ayllon BD, Moncho-Amor V, Abarrategi A, Ibañez de Cáceres I, Castro-Carpeño J, Belda-Iniesta C, Perona R and Sastre L: Cancer stem cells and cisplatin-resistant cells isolated from non-small-lung cancer cell lines constitute related cell populations. Cancer Med 3: 1099-1111, 2014.

6. Yang J, Guo W, Wang L, Yu L, Mei H, Fang S, Ji P, Liu Y, Liu G and Song Q: Cisplatin-resistant osteosarcoma cells possess cancer stem cell properties in a mouse model. Oncol Lett 12: 2599-2605, 2016 . 
7. Hanahan D and Weinberg RA: Hallmarks of cancer: The next generation. Cell 144: 646-674, 2011.

8. Yin X, Zhang BH, Zheng SS, Gao DM, Qiu SJ, Wu WZ and Ren ZG: Coexpression of gene Oct4 and Nanog initiates stem cell characteristics in hepatocellular carcinoma and promotes epithelial-mesenchymal transition through activation of Stat3/ Snail signaling. J Hematol Oncol 8: 23, 2015.

9. Loh YH, Wu Q, Chew JL, Vega VB, Zhang W, Chen X, Bourque G, George J, Leong B, Liu J, et al: The Oct4 and Nanog transcription network regulates pluripotency in mouse embryonic stem cells. Nat Genet 38: 431-440, 2006.

10. He W, Li K, Wang F, Qin YR and Fan QX: Expression of OCT4 in human esophageal squamous cell carcinoma is significantly associated with poorer prognosis. World J Gastroenterol 18 712-719, 2012

11. Lu X, Mazur SJ, Lin T, Appella E and Xu Y: The pluripotency factor nanog promotes breast cancer tumorigenesis and metastasis. Oncogene 33: 2655-2664, 2014.

12. Chiou SH, Wang ML, Chou YT, Chen CJ, Hong CF, Hsieh WJ Chang HT, Chen YS, Lin TW, Hsu HS, et al: Coexpression of Oct4 and Nanog enhances malignancy in lung adenocarcinoma by inducing cancer stem cell-like properties and epithelialmesenchymal transdifferentiation. Cancer Res 70: 10433-10444, 2010.

13. Chen YC, Hsu HS, Chen YW, Tsai TH, How CK, Wang CY, Hung SC, Chang YL, Tsai ML, Lee YY, et al: Oct-4 expression maintained cancer stem-like properties in lung cancer-derived CD133-positive cells. PLoS One 3: e2637, 2008.

14. Lu Y, Zhu H, Shan H, Lu J, Chang X, Li X, Lu J, Fan X, Zhu S, Wang Y, et al: Knockdown of Oct4 and Nanog expression inhibits the stemness of pancreatic cancer cells. Cancer Lett 340 : $113-123,2013$

15. Zhao QW, Zhou YW, Li WX, Kang B, Zhang XQ, Yang Y, Cheng J, Yin SY, Tong Y, He JQ, et al: Akt-mediated phosphorylation of Oct4 is associated with the proliferation of stem-like cancer cells. Oncol Rep 33: 1621-1629, 2015.

16. Lin Y, Yang Y, Li W, Chen Q, Li J, Pan X, Zhou L, Liu C, Chen C, $\mathrm{He} \mathrm{J}$, et al: Reciprocal regulation of Akt and Oct4 promotes the self-renewal and survival of embryonal carcinoma cells. Mol Cell 48: 627-640, 2012

17. Bleau AM, Hambardzumyan D, Ozawa T, Fomchenko EI, Huse JT, Brennan CW and Holland EC: PTEN/PI3K/Akt pathway regulates the side population phenotype and ABCG2 activity in glioma tumor stem-like cells. Cell Stem Cell 4 226-235, 2009.

18. Wang YK, Zhu YL, Qiu FM, Zhang T, Chen ZG, Zheng S and Huang J: Activation of Akt and MAPK pathways enhances the tumorigenicity of $\mathrm{CD} 33^{+}$primary colon cancer cells Carcinogenesis 31: 1376-1380, 2010.

19. Noh KH, Kim BW, Song KH, Cho H, Lee YH, Kim JH, Chung JY, Kim JH, Hewitt SM, Seong SY, et al: Nanog signaling in cancer promotes stem-like phenotype and immune evasion. J Clin Invest 122: 4077-4093, 2012

20. Rajesh E, Sankari LS, Malathi L and Krupaa JR: Naturally occurring products in cancer therapy. J Pharm Bioallied Sci 7 (Suppl 1): S181-S183, 2015.

21. Walton NJ, Mayer MJ and Narbad A: Vanillin. Phytochemistry 63 505-515, 2003.

22. King AA, Shaughnessy DT, Mure K, Leszczynska J, Ward WO, Umbach DM, Xu Z, Ducharme D, Taylor JA, Demarini DM, et al: Antimutagenicity of cinnamaldehyde and vanillin in human cells: Global gene expression and possible role of DNA damage and repair. Mutat Res 616: 60-69, 2007.

23. Srinivasan K, Platel K and Rao MVL: Hypotriglyceridemic effect of dietary vanillin in experimental rats. Eur Food Res Technol 228: 103-108, 2008.

24. Imanishi H, Sasaki YF, Matsumoto K, Watanabe M, Ohta T, Shirasu Y and Tutikawa K: Suppression of 6-TG-resistant mutations in V79 cells and recessive spot formations in mice by vanillin. Mutat Res 243: 151-158, 1990

25. Liang JA, Wu SL, Lo HY, Hsiang CY and Ho TY: Vanillin inhibits matrix metalloproteinase-9 expression through downregulation of nuclear factor-kappaB signaling pathway in human hepatocellular carcinoma cells. Mol Pharmacol 75: 151-157, 2009.

26. Lirdprapamongkol K, Sakurai H, Suzuki S, Koizumi K, Prangsaengtong O, Viriyaroj A, Ruchirawat S, Svasti J and Saiki I: Vanillin enhances TRAIL-induced apoptosis in cancer cells through inhibition of NF-kappaB activation. In Vivo 24 501-506, 2010
27. Lirdprapamongkol K, Sakurai H, Kawasaki N, Choo MK Saitoh Y, Aozuka Y, Singhirunnusorn P, Ruchirawat S, Svasti J and Saiki I: Vanillin suppresses in vitro invasion and in vivo metastasis of mouse breast cancer cells. Eur J Pharm Sci 25: 57-65, 2005.

28. Lirdprapamongkol K, Kramb JP, Suthiphongchai T, Surarit R, Srisomsap C, Dannhardt G and Svasti J: Vanillin suppresses metastatic potential of human cancer cells through PI3K inhibition and decreases angiogenesis in vivo. J Agric Food Chem 57: 3055-3063, 2009.

29. Bachelard-Cascales E, Chapellier M, Delay E and MaguerSatta V: A protocol to quantify mammary early common progenitors from long-term mammosphere culture. Curr Protoc Stem Cell Biol 1: p. Unit 1E: 7, 2012.

30. Amini S, Fathi F, Mobalegi J, Sofimajidpour H and Ghadimi T: The expressions of stem cell markers: Oct4, Nanog, Sox 2, nucleostemin, Bmi, Zfx, Tcl1, Tbx3, Dppa4, and Esrrb in bladder, colon, and prostate cancer, and certain cancer cell lines. Anat Cell Biol 47: 1-11, 2014

31. Bae S, Kim SY, Jung JH, Yoon Y, Cha HJ, Lee H, Kim K, Kim J, An IS, Kim J, et al: Akt is negatively regulated by the MULAN E3 ligase. Cell Res 22: 873-885, 2012.

32. Suizu F, Hiramuki Y, Okumura F, Matsuda M, Okumura AJ, Hirata N, Narita M, Kohno T, Yokota J, Bohgaki M, et al: The E3 ligase TTC3 facilitates ubiquitination and degradation of phosphorylated Akt. Dev Cell 17: 800-810, 2009.

33. Campbell PA and Rudnicki MA: Oct4 interaction with Hmgb2 regulates Akt signaling and pluripotency. Stem Cells 31: 1107-1120, 2013

34. David O, Jett J, LeBeau H, Dy G, Hughes J, Friedman M and Brody AR: Phospho-Akt overexpression in non-small cell lung cancer confers significant stage-independent survival disadvantage. Clin Cancer Res 10: 6865-6871, 2004.

35. Lecker SH, Goldberg AL and Mitch WE: Protein degradation by the ubiquitin-proteasome pathway in normal and disease states. J Am Soc Nephrol 17: 1807-1819, 2006.

36. Bao B, Ahmad A, Azmi AS, Ali S and Sarkar FH: Cancer stem cells (CSCs) and mechanisms of their regulation: Implications for cancer therapy. Curr Protoc Pharmacol 14: p.Unit-14.25, 2013.

37. Gargini R, Cerliani JP, Escoll M, Antón IM and Wandosell F: Cancer stem cell-like phenotype and survival are coordinately regulated by Akt/FoxO/Bim pathway. Stem Cells 33: 646-660, 2015.

38. Yu S, Shen G, Khor TO, Kim JH and Kong AN: Curcumin inhibits Akt/mammalian target of rapamycin signaling through protein phosphatase-dependent mechanism. Mol Cancer Ther 7: 2609-2620, 2008.

39. Jiang H, Shang X, Wu H, Gautam SC, Al-Holou S, Li C, Kuo J, Zhang L and Chopp M: Resveratrol downregulates PI3K/Akt/ mTOR signaling pathways in human U251 glioma cells. J Exp Ther Oncol 8: 25-33, 2009.

40. Efferth T: Stem cells, cancer stem-like cells, and natural products. Planta Med 78: 935-942, 2012.

41. Mendoza MC,Er EE and Blenis J: The Ras-ERK and PI3K-mTOR pathways: Cross-talk and compensation. Trends Biochem Sci 36: 320-328, 2011.

42. Dent P: Crosstalk between ERK, AKT, and cell survival. Cancer Biol Ther 15: 245-246, 2014.

43. McCubrey JA, Steelman LS, Chappell WH, Abrams SL, Wong EW, Chang F, Lehmann B, Terrian DM, Milella M, Tafuri A, et al: Roles of the Raf/MEK/ERK pathway in cell growth, malignant transformation and drug resistance. Biochim Biophys Acta 1773: 1263-1284, 2007.

44. Fresno Vara JA, Casado E, de Castro J, Cejas P, Belda-Iniesta C and González-Barón M: PI3K/Akt signalling pathway and cancer. Cancer Treat Rev 30: 193-204, 2004.

45. Yu CF, Liu ZX and Cantley LG: ERK negatively regulates the epidermal growth factor-mediated interaction of Gabl and the phosphatidylinositol 3-kinase. J Biol Chem 277: 19382-19388, 2002.

46. Bhummaphan N and Chanvorachote P: Gigantol suppresses cancer stem cell-like phenotypes in lung cancer cells. Evid Based Complement Alternat Med 2015: 836564, 2015.

47. Eramo A, Lotti F, Sette G, Pilozzi E, Biffoni M, Di Virgilio A, Conticello C, Ruco L, Peschle C and De Maria R: Identification and expansion of the tumorigenic lung cancer stem cell population. Cell Death Differ 15: 504-514, 2008.

48. Sun FF, Hu YH, Xiong LP, Tu XY, Zhao JH, Chen SS, Song J and Ye XQ: Enhanced expression of stem cell markers and drug resistance in sphere-forming non-small cell lung cancer cells. Int J Clin Exp Pathol 8: 6287-6300, 2015. 
49. Shi Y, Fu X, Hua Y, Han Y, Lu Y and Wang J: The side population in human lung cancer cell line NCI-H460 is enriched in stem-like cancer cells. PLoS One 7: e33358, 2012.

50. Bertolini G, Roz L, Perego P, Tortoreto M, Fontanella E, Gatti L, Pratesi G, Fabbri A, Andriani F, Tinelli S, et al: Highly tumorigenic lung cancer $\mathrm{CD} 133^{+}$cells display stem-like features and are spared by cisplatin treatment. Proc Natl Acad Sci USA 106 16281-16286, 2009.

51. Mirza AM, Gysin S, Malek N, Nakayama K, Roberts JM and McMahon M: Cooperative regulation of the cell division cycle by the protein kinases RAF and AKT. Mol Cell Biol 24: 10868-10881, 2004.

52. Testa JR and Tsichlis PN: AKT signaling in normal and malignant cells. Oncogene 24: 7391-7393, 2005.

53. Dubrovska A, Kim S, Salamone RJ, Walker JR, Maira SM, García-Echeverría C, Schultz PG and Reddy VA: The role of PTEN/Akt/PI3K signaling in the maintenance and viability of prostate cancer stem-like cell populations. Proc Natl Acad Sci USA 106: 268-273, 2009.

54. Xiang T, Ohashi A, Huang Y, Pandita TK, Ludwig T, Powell SN and Yang Q: Negative regulation of Akt activation by BRCA1. Cancer Res 68: 10040-10044, 2008.

55. Millimouno FM, Dong J, Yang L, Li J and Li X: Targeting apoptosis pathways in cancer and perspectives with natura compounds from mother nature. Cancer Prev Res (Phila) 7: 1081-1107, 2014

56. Singh $P$ and Bast F: Screening of multi-targeted natural compounds for receptor tyrosine kinases inhibitors and biological evaluation on cancer cell lines, in silico and in vitro. Med Oncol 32: 233, 2015.

57. El Khattabi I and Sharma A: Preventing p38 MAPK-mediated MafA degradation ameliorates $\beta$-cell dysfunction under oxidative stress. Mol Endocrinol 27: 1078-1090, 2013.

58. Niu H, Ye BH and Dalla-Favera R: Antigen receptor signaling induces MAP kinase-mediated phosphorylation and degradation of the BCL-6 transcription factor. Genes Dev 12: 1953-1961, 1998.
59. Deschênes-Simard X, Gaumont-Leclerc MF, Bourdeau V, Lessard F, Moiseeva O, Forest V, Igelmann S, Mallette FA, SabaEl-Leil MK, Meloche S, et al: Tumor suppressor activity of the ERK/MAPK pathway by promoting selective protein degradation. Genes Dev 27: 900-915, 2013.

60. Ley R, Balmanno K, Hadfield K, Weston C and Cook SJ: Activation of the ERK1/2 signaling pathway promotes phosphorylation and proteasome-dependent degradation of the $\mathrm{BH} 3$-only protein, Bim. J Biol Chem 278: 18811-18816, 2003.

61. Rungtabnapa P, Nimmannit U, Halim H, Rojanasakul Y and Chanvorachote P: Hydrogen peroxide inhibits non-small cell lung cancer cell anoikis through the inhibition of caveolin-1 degradation. Am J Physiol Cell Physiol 300: C235-C245, 2011.

62. Chanvorachote P, Nimmannit U, Lu Y, Talbott S, Jiang BH and Rojanasakul Y: Nitric oxide regulates lung carcinoma cell anoikis through inhibition of ubiquitin-proteasomal degradation of caveolin-1. J Biol Chem 284: 28476-28484, 2009.

63. Pongrakhananon V, Stueckle TA, Wang HY, O'Doherty GA, Dinu CZ, Chanvorachote P and Rojanasakul Y: Monosaccharide digitoxin derivative sensitize human non-small cell lung cancer cells to anoikis through Mcl-1 proteasomal degradation. Biochem Pharmacol 88: 23-35, 2014.

64. Pongrakhananon V, Nimmannit U,Luanpitpong S, Rojanasakul Y and Chanvorachote P: Curcumin sensitizes non-small cell lung cancer cell anoikis through reactive oxygen species-mediated Bcl-2 downregulation. Apoptosis 15: 574-585, 2010.

65. Castor LR, Locatelli KA and Ximenes VF: Pro-oxidant activity of apocynin radical. Free Radic Biol Med 48: 1636-1643, 2010.

66. Liu J and Mori A: Antioxidant and pro-oxidant activities of p-hydroxybenzyl alcohol and vanillin: Effects on free radicals, brain peroxidation and degradation of benzoate, deoxyribose, amino acids and DNA. Neuropharmacology 32: 659-669, 1993.

67. Tai A, Sawano T, Yazama F and Ito H: Evaluation of antioxidant activity of vanillin by using multiple antioxidant assays. Biochim Biophys Acta 1810: 170-177, 2011. 